\title{
CHANGES IN THE BEHAVIOR OF RELIGIOUS RADICALISM OF YOUNG COMMUNITIES IN THE MATARAMAN REGION, EAST JAVA
}

\author{
Nur Kholis, Munardji, Nuril Mufidah, \\ Salamah Noorhidayati, Badrus Sholeh \\ UIN Sayyid Ali Rahmatullah Tulungagung \\ UIN Sayyid Ali Rahmatullah Tulungagung \\ UIN Maulana Malik Ibrahim Malang \\ UIN Sayyid Ali Rahmatullah Tulungagung \\ UIN Syarif Hidayatullah Jakarta \\ email: nurkholisblt@yahoo.com; \\ munardji@iain-tulungagung.ac.id; \\ nurilmufidah86@uin-malang.ac.id; \\ salamahnoorhidayati@gmail.com \\ badrus.sholehuinjkt.ac.id
}

\begin{abstract}
This study aims to describe and analyze behavioral changes in religious radicalism and the factors that influence these behavioral changes. This research is qualitative research, using a case study approachconducted in the districts of Mataraman culture. The primary consideration is that the character of this region adheres to the notion of integration of religion, culture, and politics, which can be called a society with a harmonious character. The facts in the research site show this community with a culture of harmony has been exposed to radical ideas, especially among teenagers. For example, there were two raids on people suspected of being exposed to radicalism in Tulungagung. Data collection techniques are in-depth interviews, observation, and documentation. The collected data were analyzed using Miles \& Huberman's interactive model. The study results show that changes in behavior towards religious radicalization are determined by several factors, namely, the strength of belief, Daulah Islamiyyah as the subjective norm of the group, scriptural
\end{abstract}


studies, and economic programs/activities to improve the welfare of members. These four factors trigger intentions to turn into religous radicalization. A firm intention among youth serves leads to actualization of radical behavior in religion among youth.

الهلخص :تهدف هذه الدراسة إلى وصف وتحليل التغيرات السلوكية في التطرف الديني ،

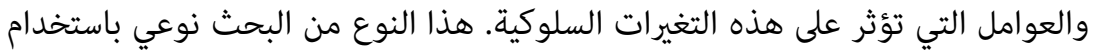

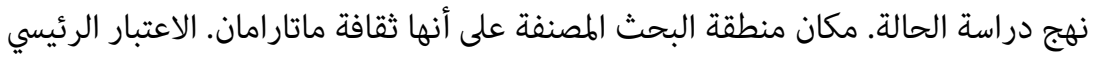

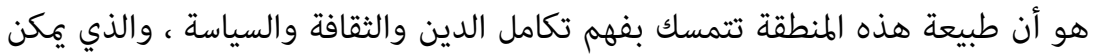

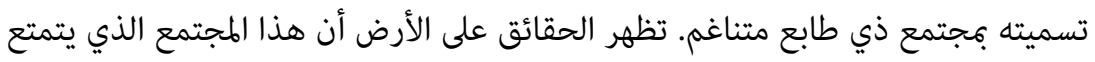

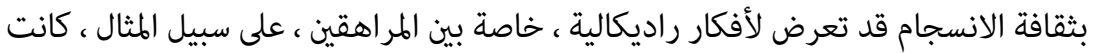

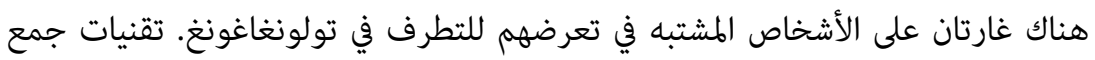

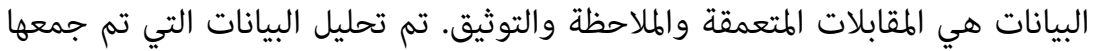

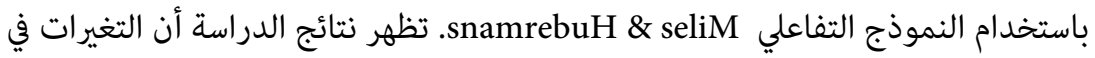

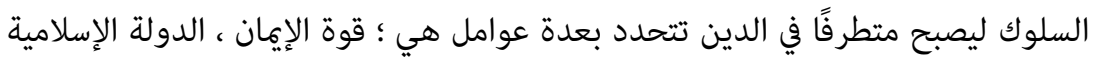

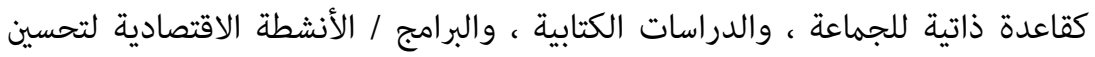

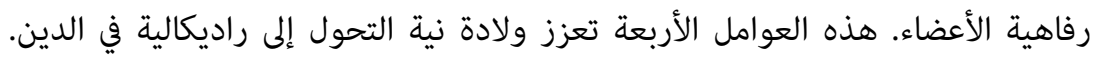
تعمل النية القوية لدى الشباب على تفعيل السلوك الر اديكالي في الدين بين الشباب.

Abtrak: Penelitian ini bertujuan untuk mendeskripsikan dan menganalisis perubahan perilaku radikalisme beragama, dan faktor-faktor yang mempengaruhi perubahan perilaku tersebut. Jenis penelitian ini adalah kualitatif dengan menggunakan pendekatan studi kasus. Tempat penelitian wilayah yang masuk kategori budaya Mataraman. Pertimbangan utamanya adalah karakter wilayah ini menganut paham integrasi agama, budaya, dan politik dapat disebut sebagai masyarakat berkarakter harmoni. Fakta di lapangan menunjukkan komunitas masyarakat yang berbudaya harmoni ini telah terpapar paham radikal terutama kalangan remaja, misalnya dua kali terjadi penggerebekan orang yang diduga terpapar paham radikal di Tulungagung. Teknik pengumpulan datanya adalah Interview mendalam, observasi, dandokumentasi.Data-datayangterkumpul dianalisis menggunakan model interaktif Miles \& Hubermans. Hasil penelitian menujukkan bahwa perubahan perilaku menjadi radikal dalam beragama ditentukan oleh beberapa faktor, yaitu; 
kekuatan keyakinan, Daulah Islamiyyah sebagai norma subyektif kelompok, kajian-kajian yang bersifat skriptural, dan program/ kegiatan ekonomi untuk meningkatkan kesejahteraan anggota. Keempat faktor ini menguatkan lahirnya niat untuk berubah menjadi radikal dalam beragama. Niat yang kuat pada kalangan pemuda berfungsi memicu aktualisasi perilaku radikal dalam beragama di kalangan pemuda.

Keywords: Behavior Change, Youth, Religious Radicalism, Mataraman

\section{INTRODUCTION}

Some experts interpret that Islamic radicalism as a form of reaction of Muslims against Western domination. ${ }^{1}$ Such radicalism is a form of rebellion against the powerlessness of Muslims. Therefore they demand the reposition of Islam over Western domination, as driven by Hasan al-Banna and Abul A'la Maududi. This radicalism is political radicalization, by establishing political organizations, namely the Muslim Brotherhood in Egypt and the Islamic Community in Indo-Pakistan. On the other hand, some understand that Islamic radicalism is rooted in relative deprivation and disorientation of values. ${ }^{2}$ Procedural, distributive, and interactional injustices are the primary triggers for developing radicalism among Muslims. Various facts show that the West, driven by the superpower United States of America, always applies double standards in dealing with Islamic countries, for example, against Iraq, Palestine, and others. The same applies to the implementation of the WTO policies, the world bank, the IMF, and other world economic institutions.

In global politics, the emergence of Islamic radicalism can be traced from the relationship between the West and Islam. ${ }^{3}$ Radicalism and terrorism then developed into issues in several countries since

1 D. Hasan, "Radikalisme Islam: Jejak Sejarah, Politik Identitas, dan Repertoire Kekerasan," in Model-model Penelitian dalam Studi KeIslaman, ed. Mu'tasim (Yogyakarta: Lemlit UIN Sunan Kalijaga, 2006), 70.

2 M.Z. Mubarak, Genealogi Islam Radikal di Indonesia (Jakarta: LP3ES, 2008), 25 .

3 Ahmad Sahide, "I SIS Bagian dari Hubungan (Respon) Islam-Barat," Ilmu Ushuluddin 2, no. 4 (2015), 359-370. 
the bombing of the World Trade Center (WTC) building. ${ }^{4}$ This unfavorable Islamic-Western relationship ultimately led to conflicts of thought and political attitudes that have continued to develop since the crusade s..$^{5}$ Narratives that corner Islam, in general, are increasingly felt lately along with the growing issue of Islamic radicalism or Islamic terrorism. ${ }^{6}$ It is undeniable that several terror incidents that occurred abroad and within the country involved individual Muslims. However, it is questionable that such incidents are global political settings or occur naturally. This relationship pattern then divides into two things. First, the West's succeeds in secularizing, separating religion from politics, Islam, church, and state. Second, some Muslims want a sharia system in the state. ${ }^{7}$

The desire to establish Islamic state of Indonesia emerged since a debate occurred at the 1956-1959 Constituent Body session. In the session, several parties were divided into three groups of opinions based on the stat e: Islam, Nationalist-secular, and Communist. ${ }^{8}$ Islamic groups assume that Islam has total values covering all world affairs, state affairs, and religious affairs. There are also concerns about the Pancasila ideology offered, which was not derived from Shari'a so that it is possible to be entered by secular values and norms. On the other hand, those who want Pancasila as the basis of the state argue that it is an open ideology that allows any ideology to conform to the values of Pancasila. ${ }^{9}$ Such debates were very intense and ended in deadlock throughout the period, forcing President Soekarno to issue a presidential decree. The roots of such conflicts of thought

${ }^{4}$ Sri Herwindy a B askara Wijaya, "Media dan Terorisme (Stereotype Pemberitaan Media Barat dalam Propaganda anti-Terorisme oleh Pemerintah Amerika Serikat di Indonesia Tahun 2002)," Jurnal The Messenger 2, no. 1 (2010): 27-41.

5 N. C. Funk and A. A. Said, "Islam and the West: Narratives of Conflict and Conflict Transformation," International Journal of Peace Studies, 2004, 1-28.

6 B. Edyar, "Religious Radicalism, Jihad And Terrorism"," AJIS 2, no. 1 (2017).

7 Karen Amstrong, Berperang Demi Tuhan: Fundamentalisme Dalam Islam, Kristen Dan Yah udi (Jakarta: Serambi, 2001), ix. Se e Leonard Binder, Islamic Liberalis m: A Critique of Development Ideologies ( $\mathrm{C} \mathrm{h}$ icago and London: The University of Chicago Press, 1988), 16-49.

8 S. Kurdi, "Gerakan Politik Masyumi dalam Membendung Komunisme Pada Masa Konstituante 1956-1959," Khazanah: Jurnal Studi Islam dan Humaniora 7, no. 1 (2009): 31-70.

9 H. W. Widayati, "Dialog Pemikiran Tentang Islam dan Negara di Indonesia Masa Awal Kemerdekaan," Jurnal Dakwah 10, no. 2 (2009): 213-228. 
remain and are latent, even though in the New Order era, President Soeharto established Pancasila as the sole principle. ${ }^{10}$

Studying religi o us teachings down to the roots, foundations, origins, and beginnings is commonplace for every religious adherent. ${ }^{11}$ However, religio us radicalism is increasingly unnatural when it is political, namely showing resistance and rejection of state conditions and systems, even trying to replace the old system with a new system fundamentally and comprehensively. ${ }^{12}$ The phenomenon of religious radicalism, which then rejects and fights, even wants to replace the established system with a new system, can be on a national and global scale. It is a reaction of Western liberalism and colonialism against the East (Islamic world). ${ }^{13}$ Therefore, religious radicalism with political nuances is growing, especially among young people in Indonesia. Therefore, serious efforts are needed from all parties to suppress the development of religious radicalism among youth because they are the nation's assets.

Youth and students are prone to be exposed to radical ideas, as identified by the National Counterterrorism Agency concerning State Universities in Indonesia exposed to radicalism. ${ }^{14}$ This vulnerability is caused by several factors, including the character of youth who are still searching for identity and life orientation. In addition, the factors of social background, gender, political values, and critical activities that have been followed have also contributed to radical behavioral changes. ${ }^{15}$ Youth religious radicalization can be analyzed with behavior change theory. Behavioral changes are determined by intentions, subjective norms, attitudes, intensity, and actions. ${ }^{16}$ In

${ }^{10}$ Widayati, 213-228.

${ }^{11}$ Pusat Bahasa D e p a rtemen Pendidikan Nasional, Kamus Besar Bahasa Indonesia (Jakarta: PT. Gramedia Pustaka Utama, 2008), 919.

${ }^{12}$ D. J. Cheal, "Political Radicalism and Religion: Competitors for Commitment," Social Compass 22, no. 2 (1975): 245-293.

${ }^{13}$ M. Marzuki, M. Mift ahuddin, and M. Murdiono, "Multicultural Education in Salaf Pesantren and Prevention of Religious Radicalism in Indonesia," Jurnal Cakrawala Pendidikan 39, no. 1 (2020): 12-25.

${ }^{14}$ B. Suyanto, M. I. Sirry, and R. Sugihartati, "Pseudo-Radicalism and The DeRadicalization of Educated Youth in Indonesia," Studies in Conflict \& Terrorism, 2019, 1-20.

${ }^{15}$ Uba Kartin and Lorenzo Bosi, "Explaining Youth Radicalism as a Positioning of the Self at Opposite Extremes," Political Studies Association Special Is (2021).

${ }^{16}$ J. L. Hale, B. J. Hous eholder, and K. L. Greene, "The Theory of Reasoned Action," in The Persuasion Handbook: Developments in Theory and Practice, vol. 14, 
addition, it can also be influenced by the perspective of people or those closest to them in responding to political issues. ${ }^{17}$

Several previous studies analyzed the causes of Islamic radicalism from the interaction between religious understanding and jihad, ${ }^{18}$ desire to free Muslims from economic inequality, and local-global political marginalization. ${ }^{19}$ On the other hand, some studies analyze the loss of ethics and morals resulting in Islamic radicalism. ${ }^{20}$ Religion for each individual is a subjective and sacred choice. Therefore, it can affect the awareness and emotions of its adherents, whichwill quickly cause conflict following a collision. ${ }^{21}$ By considering the results of previous studies, this research is focused on deepening the process of radical behavior in religion among youth. The process of radical behavior change based on the above theory is influenced by several factors as triggers and is reinforced by certain conditions.

This study aims to analyze the process of the behavior change of religious radicalism among youth. The researchers assume that among these factors are reciprocal, namely, between the factors that influence each other. For example, several previous studies have shown that ideological or belief factors lead to the development of a person's religious fanaticism, which is very likely to cause friction if triggered by other factors. Because of this, the study aims to describe the factors of religious radicalism in society. These factors can be triggers if strengthened by other factors, for example, intentions, subjective norms, intensity, and views of parents/closest people. In the end, it will change a person's attitude and behavior.

This type of research is qualitative with a case study approach in several communities and universities in East Java. The informants

2002, 259-286.

${ }^{17}$ Elga Sikkens and Marion van San, "Sieckelinck, Stijn; de Winter," Micha. Journal of Child and Family Studies 27 (2018): 2276-2284.

18 A. Venkatraman, "Religious Basis for Islamic Terrorism: The Quran and Its Interpretations," Studies in Conflict \& Terrorism 30, no. 3 (2007): 229-248.

${ }^{19}$ W. R. Jati, "Radicalism in the Perspective of Islamic-Populism: Trajectory of Political Islam in Indonesia," Journal of Indonesian Islam 7, no. 2 (2013): 268-87.

${ }^{20}$ A. Aly, E. Taylor, and S. Karnovsky, "Moral Disengagement and Building Resilience to Violent Extremism: An Education Intervention," Studies in Conflict \& Terrorism 37, no. 4 (2014): 369-385.

${ }^{21}$ A. Natalia, "Faktor-fakt or Penyebab Radikalisme dalam Beragama (Kajian Sosiologi Terhadap Pluralisme Agama di Indonesia)," Al-Adyan: Jurnal Studi Lintas Agama 11, no. 1 (2016): 36-56. 
which were selected were youth or students who had been exposed to radicalism. The focus on youth informants is based on the assumption that this period is a period of finding identity, so they are easily influenced by critical issues. The selection of informants is based on instructions or facilitated by crucial people. Researchers intensively dig up data through in-depth interviews, observation, and documentation. Friendship with informants, the intensity of meetings, and sufficient time are techniques to ensure that the data collected is valid. Data that has been collected is directly displayed, sorted/reduced according to the indicators and sub-questions of the research, and then analyzed with the relevant theory.

\section{FACTORS OF RELIGIOUS RADICALISM IN YOUTH PERSPECTIVE}

A single factor does not cause radicalism. Various factors influence the birth of radicalism among students. Respondents admitted that, in their universities, there was no mapping of student radicalism, but what was conveyed to researchers was only the result of observing facts in the field and reading theories. According to them, the determinant factors causing radicalism are beliefs, as detailed below.

"Belief in the 'truth' is an essential factor in the phenomenon of the emergence of radicalism. The belief that the truth comes from God, which is stated in the Qur'an. Socio-cultural attitudes and behaviors that develop in society should reflect or come from the Qur'an. The Qur'an is the only source of that truth. If there are verses that are not clear and difficult to apply in daily life, other verses should be found to explain or we can use interpretations of the salaf scholars. The Prophet Muhammad came as a leader and government during his leadership in Mecca and Medina. Government should be built based on the teachings of the Qur'an and the interpretation or best practice of ulama salaf." 22

The beliefs instilled by each radical community have entered the deepest recesses, thus influencing their understanding, attitudes, and behavior. Every social organization and community has ways to regenerate its members through cadre activities. Cadre is part of

22 "Interview, SW-01, 05112020". 
formal education developed by each organization so that each member has a uniform understanding, attitude, and behavior as outlined by the organization. Education and cadre are intended to instill values and beliefs to facilitate the process of achieving organizational goals. The approach commonly used in the organizational cadre is the doctrine of values, insights, and directions for organizational development. According to respondents, there are many cadre models, but they can be divided into two, namely formal and non-formal cadre, as presented below.

"The cadre is the primary key to the sustainability of the radicalism community. The method used by this group in recruiting cadres is done both formally and informally. Informal recruitment is an approach to new individuals outside the family members of the community. In comparison, the informal method is recruiting members, which is carried out systematically on members of their respective families. Most of them take the non-formal recruitment path". ${ }^{23}$

Radical community cadre in the form of doctrine to strengthen members' beliefs. The belief that the absolute truth is Allah Swt. the source of Islamic teachings is the Qur' an, the community/government management system is the khilafah, social problems stem from a government system that is not suitable to the teachings of the Prophet Muhammad. Such beliefs are part of which are reviewed regularly and periodically in non-formal forums. The authors have participated in studies conducted by this community. The themes studied in the forum are as described above. Beliefs that have been ingrained in the minds of cadres will have a strong influence on their attitudes and behavior. The militant attitude of each member reflects the beliefs that have been attached and are difficult to be influenced by other understandings.

Daulah Islamiyah has always been an essential theme in the studies conducted by this group. Powerlessness, social problems, foreign domination of the country's resources, and poverty result from a secular government. According to respondents that the primary goal of radical groups is daulah Islamiyah. As conveyed

23 "Interview, SW-03, 05112020". 
to the researcher, "the government system determines justice and prosperity. The problems faced by the Indonesian nation and state are due to mistakes in choosing a secular government system. The ideals of baldatun thayyibatun wa rabbun ghafur hint at the importance of a government system that comes from Allah, namely the khilafah system as shown in the Qur'an so that the government is just and prosperous in His blessings. ${ }^{24}$ In addition, according to them, Islam had progressed between the 7th and XI centuries Hijriyah, which at that time had a khilafah system of government.

Daulah Islamiyah is a precious thing for this group. Happiness, prosperity, and justice can be realized if the State adopts a caliphate system. According to respondents, implementing a caliphate in government is urgent at this time, as detailed below. "Countries face many problems with secular systems, such as debt bondage, poverty, moral destruction of officials and youth, ignorance, atheism, etc. Suppose we return to the caliphate government system. In that case, all the problems of the nation and society can be resolved because Islam provides precise demands and directions as stated in the Qur'an. ${ }^{25}$ They understand that the Qur'an and al-hadith teach about norms and rules regarding the management of the State. Thus, restoring the government system according to Islamic teachings is a must to realize just welfare.

According to respondents, regular internal community studies provide information that the current Khilafah system is urgent to implement, especially in Indonesia. According to him, the implementation of the caliphate system in government in Indonesia should be carried out immediately by revising the 1945 Constitution first, as stated by respondents. "We have known together that currently various problems are faced by the nation and the people in Indonesia. A bad government system causes such social problems. Therefore, we believe replacing the Islamic system in carrying out the nation's life and state". ${ }^{26}$ Knowledge and understanding were obtained from the interpretation of the verses of al-Qur'an and studies obtained from their community. Studies that are routinely

\footnotetext{
24 "Interview, SW-02, 06112020".

25 "Interview, SW-01, 07112020".

26 "Interview, SW-05, 07112020".
} 
carried out by this community are based on the Qur' an and al-Hadith by their leaders.

Radical communities that have begun to develop in several campuses always hold regular religious studies. The study materials are mainly the Qur'an which is translated and interpreted literally. According to respondents, the study approach carried out by the radical community is scripturalist. Radical knowledge and attitudes developed in a small part of campus because of the scriptural approach to study, namely the study of the Koran that was uprooted from its context. The Qur'an contains local content which is based on a particular time, mutasyabbihat, and by the conditions in which the verses were revealed. For example, the verse about "Kill them wherever you find them" (QS. al-Baqarah: 191; QS. al-Nisa': 89, 91). According to respondents, these verses of the Qur'an must be interpreted with other verses or with al-Hadith, not necessarily with logic, let alone understanding the context. ${ }^{27}$

The respondents saw that the Qur'an is a qaul of the most genuine essence, so the truth should not be interpreted with qaul or human logic that is very limited (relative). As conveyed to the researchers, "it does not make sense or funny that the absolute truth of the Qur' an should be interpreted with the views, opinions, or books written by humans. The human mind and five senses are relative, or their abilities are limited, so how can a little thing be used as a tool to analyze or interpret the absolute". ${ }^{28}$ The correct interpretation of the Qur'an is based on other verses in the Qur' an. Suppose the verses are not available as an explanation of the verses of mutasyabbihat. In that case, it is necessary to look for hadiths so that the understanding of the verse is more comprehensive.

The radical community has a well-scheduled study group. Members who attend from their internal circles, even if new members, are usually present with their friends, who have previously become members. The study is led by people distinguished by science, experience, and seniors in the organization. The resource person held the Qur'an and several books as references. The material studied was based on the order of the verses (not thematic), according to what the researcher heard and knew that in the study, the sources used other

27 "Interview, SW-04, 08112020".

28 "Interview, SW-02, 09112020". 
related verses as the basis for interpreting them. The hadiths are also used to strengthen the views, interpretations, and conclusions of a problem being studied. According to this community's general view, the studies carried out by them routinely use a scripturalist approach.

The scripturalist approach in studying Islamic religious and social issues tends to ignore contextual factors. The government is one of the objects of study that is considered inappropriate or deviates from the teachings of Islam. The practice of government in Indonesia is considered to violate the system of government described in the Qur'an. The sentence that the Unitary State of the Republic of Indonesia (NKRI) is structured based on one Godhead, as summarized in the preamble to the 1945 Constitution, must be interpreted as Allah Swt. Therefore, the implementation and all government apparatus should be based on Islam. If left as is now practiced by the Indonesian government, then all policies and regulations implemented by the State must be interpreted as contradicting the mission of Islam. All policies and regulations implemented by the secular State are not required to be followed, as conveyed to the researchers.

"The state has deviated from the basic idea of establishing the Republic of Indonesia, which is based on one God. God Almighty is Allah Swt. Apart from Allah, there is not one God. Therefore, there is no other choice for the basis of government implementation, except that it must be based on the Qur'an and al-Hadith. The two sources of religious teachings should be the primary sources in preparing laws, regulations, and government policies. Thus, a state that is not based on the Qur'an and al-Hadith we are not obliged to follow it. ${ }^{29}$

The government has been ignoring the mandate of the Preamble of the 1945 Constitution. Therefore, now many people are starting to distrust the government. Such themes become the focus or object of study by radical groups. They do not want to be blamed, especially now that many kyai or religious leaders are being arrested and imprisoned. Respondents to researchers said, "Lately there has been a phenomenon of Islamophobia which is marked by the imprisonment of several kyai who are "opponents" of the government, clashes

29 "Interview, SW-05, 08112020". 
between religious communities, terrorist stigma, and tightening of permits for religious activities. This phenomenon is a turning point for people's distrust of the government..$^{30}$ In addition, the government's alignment prioritizes the interests of capitalists and foreign countries, as expressed by respondents, "the government favors the interests of foreign countries and capitalists a lot, and has minimal alignment with the poor people." ${ }^{11}$

Radical groups consider the government's policies as a trigger for their distrust. They believe that the government has departed from the ideals of the nation as expressed to researchers, "The government has deviated from the ideal function to protect the entire Indonesian nation and the entire homeland of Indonesia and to promote public welfare, educate the nation's life. For this reason, our trust starts vanishing. The government is no longer a medium for prosperity and welfare". ${ }^{32}$ According to them, studies that criticize government policies are intended to provide a different perspective and generate new awareness to make alternative programs and activities. As conveyed to the researcher, "the government does not want to accept input from the people. Therefore it is better for the people to carry out critical activities and directly touch poor people, both in the fields of politics, economy, and regeneration". ${ }^{33}$

Members involved in systematic studies, both on-campus and off-campus, are primarily young people. According to respondents, the main reason for joining this radical group is economics, as stated by the researcher. "The first time I joined this group because of the lure of work. At that time, I was still graduating from high school, having difficulties not being able to go to college because of the poor economy of my parents". ${ }^{34}$ According to the respondents, after becoming a group member, he was always approached through the following activities; increasing religious knowledge, skills and work, and cadre training. The programs and activities of this group are focused on three main things: network and economic development, religious knowledge and insight, and cadre levels. The network of

\footnotetext{
30 "Interview, SW-03, 10112020".

31 "Interview, SW-5, 09112020".

32 "Interview, SW-01, 11112020".

33 "Interview, SW-04, 12112020".

34 "Interview, SW-06, 12112020".
} 
this group is powerful, disciplined, and closed. At first, it was pretty tricky for the researchers to enter this group, but the researchers finally got access after contacting the key people the researchers knew.

This group has economic empowerment and assistance programs for members. The program is implemented by involving third parties, such as founders, investors, and financial institutions. According to the respondent, the assistance was carried out intensively. As conveyed to the researcher, "The facilitators of the empowerment program and economic assistance carried out by the group follow a strict schedule and orientation. They were starting from the determination of activities and implementation and evaluation. ${ }^{35}$ Based on the documentation, most economic programs developed are in the service sector, trade, and agriculture. Mentoring is done through networks that are formed within the internal group. Group members quite enjoy the developed economic business, and the most important thing is that they can attend congregational prayers according to their respective zones.

Interest in radical groups was initially triggered by promises of economic convenience. For example, getting a job, joining work, venture capital, business assistance, and the provision of capital or work tools. Every prospective member who is recruited is promised to improve his/her economy and his family and convenience of setting up a new business, business capital, business tools, business assistance, assistance in establishing business cooperation with third parties (old member/network), and business development" ${ }^{36}$ Mentoring and business development of members is an essential part of group programs and activities and systematic religious studies conducted every month. During the religious study meeting, monitoring, evaluating, and mentoring the business development of members are also carried out.

Economic programs and activities are one of the main recruitment strategies of the radical groups. The economy for individuals and groups/organizations is the key to the economic sustainability of families and organizations. For them, member economies develop automatically increase the group's attractiveness and source of

35 "Interview, SW-05, 13112020".

36 "Interview, SW-02, 08122020". 
organizational budget and expenditure revenue. The informant conveyed to the researcher as follows, "becoming a member of a group/organization is required to have "sedekah lillah" (charity for the sake of God) taken from the business profits of the assisted members. The results of this charity are used for program costs and organizational activities. Every month, in the religious study forum, the amount of alms received from members and their expenditures are always published. ${ }^{37}$ Thus, members become more and more confident in the transparency or trust of the management. Charity for them is one of the $d a$ 'wah for realizing the glory and honor of Islam.

After becoming members, they are invited to watch videos, give discourses, and discuss government policies. The goal is to make them follow and participate in religious study meetings and other community activities. The purpose of these programs and activities is to create awareness and hatred towards the government. The hatred embedded in the members is expected to trigger the birth of a grudge against the government. "According to our leadership, the hurt and resentment against the government are not due to personal interests. What is more important is that we criticize government policies, programs, and activities that are considered not in favor of marginalized people and communities. Muslims and kyai have always been hostile to the government" ${ }^{38}$

The hatred of radical groups is directed at the government and parties considered allied with the government to keep Muslims away from power and marginalize them in a planned and systematic manner. To vent the hatred, they created a program that rivaled government policy, as presented to researchers. "Hatred and resentment against the government and allied parties make our group create programs and competitions that focus on critical attitude and member empowerment, so as not to depend on the government-for example, economic empowerment programs, cadres, and the strengthening of monotheism. Monotheism is required so that members only depend on Allah Swt. and be hard on the infidels and tyrannical governments". ${ }^{39}$ The government was considered a group of modern imperialism, disguised as rulers but cruel to the people.

\footnotetext{
37 "Interview, SW-06, 07122020".

38 "Interview, SW-04, 15122020".

39 "Interview, SW-02, 15122020".
} 
For this group, Indonesia has not yet become a true independent country. As conveyed to the researcher, "Indonesia has indeed become independent from the Dutch and Japanese imperialists, but now what we feel is that Indonesia is not an independent country. We are still colonized by the policies and desires of certain groups and developed countries, such as America, Europe, and China". ${ }^{40}$ Especially the current government tends to cooperate with China. Developed countries still control Indonesia's programs, policies, and development under the guise of cooperation. The cooperation developed by the government is more profitable for the investor country, "Developed countries as investors enjoy more benefits than Indonesia, for example, the construction of Java toll roads, bridges, construction of OBOR, coastal reclamation, and capital new city. I think the government will cooperate with capitalists from China" ${ }_{41}$

Radical groups are eager to change an increasingly powerless system in front of capitalists and developed countries. They are of the view that it can become a developed country if the Qur'an and al-Hadith are used as the basis for development, as conveyed to researchers as follows. "Imperialism is still entrenched in Indonesia in the form of no longer physically. Developed countries control planners and development processes. They provide loans and channel their expertise as a condition for loan disbursement..$^{42}$ Inevitably, this group believes that complete and comprehensive change should be a priority so that the government is truly the controller of the planning and development process. "Changes in the government system are urgent and the main choice, because historically Islam has progressed in the Middle Ages by consistently making Islam the basis of the state". ${ }^{43}$

\section{RADICAL BEHAVIOR CHANGES IN RELIGION}

The factors that cause the growth and development of Islamic radicalism based on the findings of this study can be grouped into two main classifications: ideological and non-ideological factors. The ideological factor is the belief to fight for the replacement of

\footnotetext{
40 "Interview, SW-05, 15122020".

41 "Interview, SW-04, 15122020".

42 "Interview, SW-06, 15122020".

43 "Interview, SW-03, 15122020".
} 
the ongoing system with a system and order of Islamic values in the life of the nation and society, which is considered to improve welfare and justice for the people and the nation. ${ }^{44}$ According to previous research, such belief is based on the view that Islam is a comprehensive religion. It is believed that comprehensive Islamic teachings can be implemented in state and national life. Thus, for this group, Islam regulates the mahdhah (obligatory worship) and regulates muamalah, including how to regulate an Islamic State.

Radical groups have consistetnly argued that various social problems experienced by secular countries are caused by a seculargovernment system. The Ottoman Turkish caliphate government system is believed to be one of the barometers that have succeeded in delivering the welfare of the people and the Ummah. The post-Ottoman Turkish government is the development of a modern secular government system. In fact, until the 21 st century, the people have not enjoyed independence. For this reason, the caliphate system is believed to be the right solution to guard and realize the welfare of the people based on the values and norms of Islamic teachings, which are directly taught by the Almighty, Allah Swt. The Khilafah system aims to overcome the deteriorating situation, infiltration, the need for transformational change, and ending the occupation of Muslim territories. $^{45}$

The purpose of establishing the Islamic State is as an instrument of pressure to decide matters relating to the lives of many people. The basis of social decisions will have a good impact on society if they are based on the values of Islamic teachings. Islamic values and norms not only regulate individual human relationships with other humans and with God but can also be used to regulate the government. One of the verses of the Qur'an that is used as the basis for fighting for the Islamic State is QS. al-Nur: 55. This verse explains that humans should decide all matters of the people based on Islam. The teachings of Islam cannot possibly be used as a basis for deciding social problems if the government system is still secular. Thus, they believe

${ }^{44}$ E. Laisa, "Islam dan Radikalisme," Islamuna: Jurnal Studi Islam 1, no. 1 (2014): 1-18.

${ }^{45}$ I. Akbar, "Khilafah Islamiyah: Antara Konsep dan Realitas Kenegaraan (Republik Islam Iran dan Kerajaan Islam Arab Saudi)," Journal of Government and Civil Society 1, no. 1 (2018): 95-109. 
that the caliphate system is a mandate for humankind to be realized in the daily life.

The desire to realize the Islamic State in the life of the nation and state in Indonesia is a significant part of the ideals of Islamic radicalism. This ideal is a solution to the decline of the Islamic ummah and countries with a majority Muslim population. For radical groups, the decline of Islamic countries is caused by implementing a secular system of government. Secular government has resulted in interrelated social problems, such as poverty, ignorance, foreign debt, state dependence on developed countries, poor health, and the lack of freedom of business, and association. The social problems faced by the Indonesian state have given rise to speculation among radicals that all of them are the result of the implementation of a secular system of government. Based on historical experience, the application of Islamic sharia in government causes the government to prosper the people, as experienced by the Ottoman Turks.

The idea of daulah Islamiyah promoted by the political organization Hizbut Tahrir Indonesia (HTI) is contrary to the ideals of the establishment of the Unitary State of the Republic of Indonesia. For the Indonesian people, the government system based on Pancasila is final and cannot be contested by anyone, even HTI. The nation's founding fathers have accepted Pancasila as the only pillar of the state, which underlies the Indonesian government. Pancasila is understood as the basis of open government, meaning that any religious values and development paradigms (eg liberal) can be entered as long as they do not conflict with national ideals. Incorporating the values of Islamic teachings into the government system does not have to change the system. For example, NU and Muhammadiyah have succeeded in filling out and contributing to sufficient development through integration, acculturation, and contributing models in the nation-building process.

The radicalism movement began in the 2000 s, marked by the destruction of the world trade center (WTC) in the United States. ${ }^{46}$ Since then, the discourse of terrorism has grown like a leaf in the spring. All countries condemned and declared war against terrorism movements, even in Indonesia. Densus 88 was formed under

${ }^{46}$ R. Windiani, "Peran Indonesia dalam Memerangi Terorisme," Jurnal Ilmu Sosial 16, no. 2 (2017): 135-152. 
the command of the Indonesian National Police. In subsequent developments, not only terrorism but also the discourse of radicalism, deradicalization, and Islamic moderation. The phenomenon of radicalism is a symptom that occurs in almost all religions. The radicalism of the Sikhs was harsh against the Muslims in South India. The violence for the sake of the Jewish violence against the Muslims in Palestine. Likewise, radical Christian violence occurred in Europe and America, and most recently, the tragedy of the massacre and ethnic cleansing of Rohingya Muslims in Burma, Myanmar. ${ }^{47}$

An interesting phenomenon from the subsequent development is the involvement of young people in every radical action, both in Indonesia and abroad. Some radical violent activities involving young people, for example, occurred in Solo, Surabaya, and Jakarta. The involvement of young people in cases of radicalism is interesting to study further. Young people make most people more vulnerable to an identity crisis. ${ }^{48}$ The identity crisis phase causes young people in their development to experience cognitive opening. ${ }^{49}$ The cognitive opening is a micro-sociological process that brings them closer to accepting new, more radical ideas. It is easy for young people to accept new ideas that are more challenging, among others, because they are by the development of their libido, emotions, and morals.

Radical groups view Islam as a religion and ideology. They are fighting for Islam kaffah and referring religious understanding and practice on the pious generation of salaf(salafal-șālihìn). They are also hostile to the West because it is against the teachings of Islam (kafir). They offend the liberal Islamic groups because they are considered to have destroyed Islam with a rational and contextual interpretation of religion..$^{50}$ As an ideology, Islam is a source of thinking, attitude, and behavior concerning God, fellow human beings, and other living creat ures. The teachings and values of Islam are understood textual so that it gives birth to an attitude of radicalism, exclusivity, intolerance

${ }^{47}$ A. B. Rozi, "Radikalisme dan Penyimpangan Ideologi Gerakan Salafi," Empirisma 26, no. 1 (2017), 107-116.

${ }^{48}$ Erik H. Erikson, Identity: Youth and Crisis (London: Faber \& Faber, 1968), 312.

${ }^{49}$ Quintan Wictorowitcz, Radical Islam Raising: Muslim Extremism in The West (Rowman \& Littlefield Publishers, 2005), 109.

${ }^{50}$ Hamami. Zada, Islam Radikal, Pergulatan Ormas-ormas Islam Garis Keras di Indonesia (Jakarta: Teraju, 2002), 34. 
to all other ways of thinking. ${ }^{51}$ Islam is understood textually and used as a paradigm in daily life without paying attention to the social dynamics of its people.

Islam has two dimensions: the dimension of the source of teachings or ideas and the ideological dimension. In the dimension of ideas/sources of teachings, Islam is here to be studied, understood, and the basis for implementing the daily behavior of its people. It applies as the model; dialectic, acculturation, and syncretization between Islam and social values. As an ideology, Islam is present as a "solution" for the problems faced by society. In this dimension, Islam is understood textually. The attitudes and behaviors that people implement in their daily lives are behavior without criticism. Ideological Islam comes with full power. It does not want human creativity to translate, interpret, and analyze Islamic teachings according to the dynamics of their society.

Radical groups usually have agendas that have been prepared to be fought for through their programs and activities. Some of their agendas are the unity of religion and the state, the application of shari' ah (tathbiq shari'ah), and even by promoting the concept of the caliphate, the idea of purification of Islam as a way of life, liberating Muslims from western influences, the creation of an ideal society according to Islamic teachings, the da'wah movement of amar ma'ruf and nahi munkar, whether carried out in a soft or hard way. Thus, understanding Islam is seen as a way of life and ideology to be implemented in a textual way in daily life. ${ }^{52}$

Ideology has three functions: first, ideology gives meaning; second, ideology simplifies life; third, ideology creates certainty. Ideology is a set of value systems that is resulted from social reflection of the community, which in turn is used to regulate the community's social life..$^{53}$ The values and norms produced by radical groups are the results of textual interpretation of the Qur'an and al-Hadith. These two scriptures are understood as sources of knowledge that should not be interpreted using the human reason that is relative because the

${ }^{51}$ Zainuddin. Maliki, Rekonstruksi Teori Sosial Modern (Yogyakarta: Gajah Mada University Press, 2012), 27.

${ }^{52}$ M. Thoyyib, "Radikalisme Islam Indonesia," TA'LIM: Jurnal Studi Pendidikan Islam 1, no. 1 (2018), 90-105.

${ }^{53}$ Supawi. Pamenang, "Filsafat Sosial Karl Mark," Suhuf XVII, no. 1 (2005), 5060. 
Qur' an and al-hadith are absolute. Relativity or all objects that are relatively illogical can interpret something true. Absolute truth can only be interpreted based on things that are also absolute.

The development of an Islamic caliphate can be analyzed from four things: will, power, discipline, and regime. ${ }^{54}$ Islamic radicalism is closely related to the will of the parties who construct it, both from within Islam and outside Islam, the power that surrounds it, both from within Islam and outside Islam, discipline that surrounds it, regulate it, and the regime in power. Although there are internal and external factors of Islam, the reality shows that the current controller of these four things globally is the West. In the Qur'an and al-Hadith, nothing teaches or allows violence, radicals, and killing. Regimes controlled by external powers can be part of the growing desire of radical groups to realize their ideals.

Some Islamic groups are ultra-conservative. Historically, the da'wah approach carried out by Muslims in Indonesia has used two, namely; First, the acculturation approach between the values of Islamic teachings and local culture; Second, the purification approach of Islamic teachings. The Wali Songo also uses these two approaches; Sunan Giri, for example, represents a group that uses a purification approach. Meanwhile, Sunan Kalijaga represents a group that uses an acculturation approach to local culture with Islamic values. In subsequent developments, religious organizations in Indonesia can also be grouped into two: organizations that use a purification approach to Islamic teachings, including Muhammadiyah, Salafi, HTI, etc. Meanwhile, Nahdhatul Ulama' represents a group that uses a syncretistic and acculturation approach.

The two approaches to preaching are being clashed recently, especially after the destruction of the WTC inthe United States of America. SThus, it needs to be criticized, whether it is caused by a clash of civilizations, religion, or ethnicity. ${ }^{55}$ It has been argued that Islam is the basis of terrorism, radicalism, violence, and murder. ${ }^{56}$ This issue was raised in response to the theory of the clash of

${ }^{54}$ H.L. Dreyfus, Paul Rabinow, and Michel Foucault, Beyond Structuralism and Hermeneutics Hemeld Hemspstead (Harvester: Wheatsheaf, 1982), 44.

${ }^{55}$ J. Fox, "Clash of Civilizations or Clash of Religions: Which Is an More Important Determinant of Ethnic Conflict?," Ethnicities, 1, no. 3 (2001), 295-320.

${ }^{56}$ S. Abdi, "Beyond Clash of Civilizations and Global War on Terror," Millah: Jurnal Studi Agama 6, no. 1 (2016): 17-22. 
civilizations. In this theory, Islam is the natural enemy of western civilization. ${ }^{57}$ Therefore, all social media are framed to corner Islam. Islamic groups considered violent, and use an Islamic purification approach, are scenarios as real perpetrators of violence and terrorism. In fact, in various countries, efforts to fight terrorism and radicalism are encouraged.

The behavior of radicalism among youth can be analyzed with the theory of reasoned action (TRA).$^{58}$ Radical behavior begins with intention. The emergence of intentions is usually caused by several factors, including; knowledge, the strength of beliefs, and evaluation of those beliefs. This is what gives birth to attitude. On the other hand, norm belief, and motivation to adhere to a belief can give birth to subjective norms. Subjective norms are defined as a person's perception of social pressure to perform a behavior. ${ }^{59}$ Attitudes and subjective norms lead to the emergence of an intention to do something that has been considered (evaluated and analyzed previously). Moreover, finally, someone's intention to get stronger gives birth to the will to do something.

Formal and non-formal forums organized by radical groups regularly are intended to provide all members with knowledge. This knowledge serves to strengthen the belief that a change from secular national conditions is a necessity. The subjective norm developed in this group is the formation of the Daulah Islamiyyah. For this reason, appropriate conditions and moments are created, namely, routinely conducting scriptural studies. Programs and activities are developed to achieve shared (economic) prosperity. The result of all of this is the intention to change religious behavior to become more radical. Moreover, the intention is an essential condition for giving birth to the will to do it naturally. Based on the analysis above, changes in radical religious behavior among youth can be described as follows:

${ }^{57}$ S. P. Huntington, (2000). “The Clash of Civilizations?” In Culture and Politics (New York: Palgrave Macmillan, 2000), 99-118.

${ }^{58}$ M. Fishbein and I. Ajzen, "Theory-Based Behavior Change Interventions: Comments on Hobbis and Sutton," Journal of Health Psychology 10, no. 1 (2005), 27-31.

${ }^{59}$ K. Yang and L. D. Jolly, "The Effects of Consumer Perceived Value and Subjective Norm on Mobile Data Service Adoption Between American and Korean Consumers," Journal of Retailing and Consumer Services 16, no. 6 (2009), 502-508. 


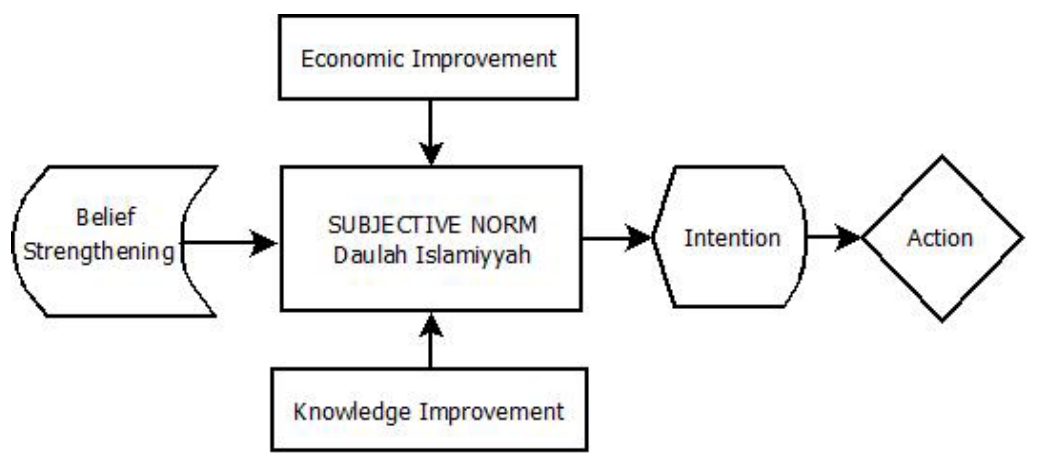

Adopted from Theory of Planned Behavior (TPB)

\section{CONCLUSION}

The intention to make radical changes in religious behavior among youth was preceded by several factors, namely, strength of belief, subjective norms of Daulah Islamiyyah, formal and non-formal studies in scriptural ways, and welfare (economic) improvement programs for members. These factors serve to shape and strengthen the intentions of members of the radical community. The strength of belief in each member is determined by increasing knowledge, both formally and informally. Daulah Islamiyyah is a shared goal and functions as a form of subjective norms for the group. This ideal because of facts the nation that is "less" in favor of the people's interests. Studies, training, seminars, and discussions formally and informally serve to increase and maintain knowledge according to the group's interests. Meanwhile, programs and activities to improve and developed to strengthen the bond between members and the group.

Some improvements can be made from this research, including; First, from the aspect of research methods. It is necessary to explore the views and meanings of the people around the youth, for example, parents, peers, social environment, and educational environment. Second, it is necessary to explore the educational environment. Based on the theory of social behavior, it is essential that changing a person's behavior begins with an understanding of ideas. The wrong understanding and interpretation or intentional by educational institutions is an essential factor in religious radicalism. Third, changing the paradigm in understanding religious radicalism in society. Moreover, it is necessary not always to place the community 
as perpetrators of religious radicalism but also as victims of local and global political systems and policies.

There should be new subjects, research methods, and paradigms in understanding religious radicalism in society. An in-depth study is needed to investigate whether religious radicalism is a fact, an issue, or just Western propaganda. Several theoretical studies and field research should focus more on "Islamic teachings" as a trigger for the development of religious radicalism, violence, and local and global terrorism. Furthermore, not many have studied the scenario behind religious radicalism and terrorism, from where the State's financial resources are allocated to fight terrorism and religious radicalism, which countries are behind the blaming of Islam as a propagator of religious radicalism. A comprehensive study will help to carry out mapping and reduction, including tackling religious radicalism more wisely.

\section{REFERENCES}

Abdi, S. "Beyond Clash of Civilizations and Global War on Terror." Millah: Jurnal Studi Agama 6, no. 1 (2016).

Akbar, I. "Khilafah Islamiyah: Antara Konsep dan Realitas Kenegaraan (Republik Islam Iran dan Kerajaan Islam Arab Saudi)." Journal of Government and Civil Society 1, no. 1 (2018).

Aly, A., E. Taylor, and S. Karnovsky. "Moral Disengagement and Building Resilience to Violent Extremism: An Education Intervention." Studies in Conflict \& Terrorism 37, no. 4 (2014).

Amstrong, Karen. Berperang Demi Tuhan: Fundamentalisme dalam Islam, Kristen dan Yahudi. Jakarta: Serambi, 2001.

Binder, Leonard. Islamic Liberalism: A Critique of Development Ideologies. Chicago and London: The University of Chicago Press, 1988.

Cheal, D. J. "Political Radicalism and Religion: Competitors for Commitment." Social Compass 22, no. 2 (1975). 
Dreyfus, H.L., Paul Rabinow, and Michel Foucault. Beyond Structuralism and Hermeneutics Hemeld Hemspstead. Harvester: Wheatsheaf, 1982.

Edyar, B. "Religious Radicalism, Jihad And Terrorism"." AJIS 2, no. 1 (2017).

Erikson, Erik H. Identity: Youth and Crisis. London: Faber \& Faber, 1968.

Fishbein, M., and I. Ajzen. "Theory-Based Behavior Change Interventions: Comments on Hobbis and Sutton." Journal of Health Psychology 10, no. 1 (2005).

Fox, J. "Clash of Civilizations or Clash of Religions: Which Is an More Important Determinant of Ethnic Conflict?" Ethnicities, 1 , no. 3 (2001).

Funk, N. C., and A. A. Said. "Islam and the West: Narratives of Conflict and Conflict Transformation." International Journal of Peace Studies, 2004.

Hale, J. L., B. J. Householder, and K. L. Greene. "The Theory of Reasoned Action." In The Persuasion Handbook: Developments in Theory and Practice, Vol. 14, 2002.

Hasan, D. "Radikalisme Islam: Jejak Sejarah, Politik Identitas, dan Repertoire Kekerasan." In Model-model Penelitian dalam Studi KeIslaman, edited by Mu'tasim. Yogyakarta: Lemlit UIN Sunan Kalijaga, 2006.

Huntington, S. P. (2000). "The Clash of Civilizations?" In Culture and Politics. New York: Palgrave Macmillan, 2000.

Jati, W. R. "Radicalism in the Perspective of Islamic-Populism: Trajectory of Political Islam in Indonesia." Journal of Indonesian Islam 7, no. 2 (2013).

Kartin, Uba, and Lorenzo Bosi. "Explaining Youth Radicalism as a Positioning of the Self at Opposite Extremes." Political Studies Association Special Is (2021). 
Kurdi, S. "Gerakan Politik Masyumi dalam Membendung Komunisme pada Masa Konstituante 1956-1959.” Khazanah: Jurnal Studi Islam dan Humaniora 7, no. 1 (2009).

Laisa, E. “Islam Dan Radikalisme.” Islamuna: Jurnal Studi Islam 1, no. 1 (2014).

Maliki, Zainuddin. Rekonstruksi Teori Sosial Modern. Yogyakarta: Gajah Mada University Press, 2012.

Marzuki, M., M. Miftahuddin, and M. Murdiono. "Multicultural Education in Salaf Pesantren and Prevention of Religious Radicalism in Indonesia." Jurnal Cakrawala Pendidikan 39, no. 1 (2020).

Mubarak, M.Z. Genealogi Islam Radikal di Indonesia. Jakarta: LP3ES, 2008.

Natalia, A. "Faktor-faktor Penyebab Radikalisme dalam Beragama (Kajian Sosiologi Terhadap Pluralisme Agama di Indonesia)." Al-Adyan: Jurnal Studi Lintas Agama 11, no. 1 (2016).

Pamenang, Supawi. "Filsafat Sosial Karl Mark." Suhuf XVII, no. 1 (2005).

Pusat Bahasa Departemen Pendidikan Nasional. Kamus Besar Bahasa Indonesia. Jakarta: PT. Gramedia Pustaka Utama, 2008.

Rozi, A. B. "Radikalisme Dan Penyimpangan Ideologi Gerakan Salafi." Empirisma 26, no. 1 (2017).

Sahide, Ahmad. "ISIS Bagian Dari Hubungan (Respon) IslamBarat." Ilmu Ushuluddin 2, no. 4 (2015).

Sikkens, Elga, and Marion van San. "Sieckelinck, Stijn; de Winter." Micha.Journal of Child and Family Studies 27 (2018).

Suyanto, B., M. I. Sirry, and R. Sugihartati. "Pseudo-Radicalism and The De-Radicalization of Educated Youth in Indonesia." Studies in Conflict \& Terrorism, 2019.

Thoyyib, M. "Radikalisme Islam Indonesia." TA 'LIM: Jurnal Studi Pendidikan Islam 1, no. 1 (2018). 
Venkatraman, A. "Religious Basis for Islamic Terrorism: The Quran and Its Interpretations." Studies in Conflict \& Terrorism 30, no. 3 (2007).

Wictorowitcz, Quintan. Radical Islam Raising: Muslim Extremism in The West. Rowman \& Littlefield Publishers, 2005.

Widayati, H. W. "Dialog Pemikiran Tentang Islam dan Negara di Indonesia Masa Awal Kemerdekaan." Jurnal Dakwah 10, no. 2 (2009).

Wijaya, Sri Herwindya Baskara. "Media dan Terorisme (Stereotype Pemberitaan Media Barat dalam Propaganda Anti-Terorisme oleh Pemerintah Amerika Serikat di Indonesia Tahun 2002)." Jurnal The Messenger 2, no. 1 (2010).

Windiani, R. "Peran Indonesia Dalam Memerangi Terorisme." Jurnal Ilmu Sosial 16, no. 2 (2017).

Yang, K., and L. D. Jolly. "The Effects of Consumer Perceived Value and Subjective Norm on Mobile Data Service Adoption Between American and Korean Consumers." Journal of Retailing and Consumer Services 16, no. 6 (2009).

Zada, Hamami. Islam Radikal, Pergulatan Ormas-ormas Islam Garis Keras di Indonesia. Jakarta: Teraju, 2002. 